\title{
Local Government Services and Social Margins: The Case of Plantation Community in Sri Lanka
}

\author{
S. Vijesandiran ${ }^{1} \&$ R. Ramesh ${ }^{2,3}$ \\ ${ }^{1}$ Department of Economics and Statistics, University of Peradeniya, Sri Lanka \\ ${ }^{2}$ Department of Administration and Organization Theory, University of Bergen, Norway \\ ${ }^{3}$ Department of Political Science, University of Peradeniya, Sri Lanka \\ Correspondence: R. Ramesh, Department of Administration and Organization Theory, University of Bergen, \\ Norway. E-mail: ramnaresh45@yahoo.com
}

Received: June 6, 2016 Accepted: August 4, 2016 Online Published: November 30, 2016

doi:10.5539/jpl.v9n10p59 URL: http://dx.doi.org/10.5539/jpl.v9n10p59

\begin{abstract}
Decentralization and local governance have been perceived as an effective tool for efficient, accountable, responsive and impartial public service delivery to all segments of citizens irrespective of ethnicity, race, gender, caste, language, social groupings etc. This paper, thus, throws more light on local government service delivery in the minority regions, especially looking at the status of plantation community in the local governance structures in Sri Lanka. The study finds that although Sri Lanka has adopted decentralized local government system at different levels, it has often been failed to effectively accommodate and address interests of ethno-linguistic minorities -Plantation Tamils. Exclusion of the plantation community in the service delivery of local government authorities has been a significant flaw of local government system which fundamentally challenges the notion of inclusive state, quality of government and democracy. The study particularly explores major factors that preclude plantation community from enjoying local government services. This issue, thus, stems a critical question about their status of citizenship rights and quality of governance in Sri Lanka. This study also may be a reflection of the plight of minorities in other multi-ethnic nations where discriminatory laws and policies affect right to access local governance and democracy.
\end{abstract}

Keywords: decentralization,local government authorities, plantation community, Sri Lanka, service delivery

\section{Introduction}

Decentralization paves way to empower weaker sections of the state by accommodating them effectively in governance structures, for which local government system has been used as a central mechanism -especially in developing countries.It is widely argued that one of the major objectives of decentralized local government system is to effectively deliver public services at the local level in an inclusive manner. Multi-ethnic nations have increasingly been adopting decentralization and local government to promote and foster the rights and interests of minorities groups. In fact, this approach has been seen as better strategy to resolve conflict, promote regional development, empower minorities, and ensure inclusive governance and democracy. Importantly, in the recent past, the term inclusive state and quality of government have been gaining immense attention in the western democracies which significantly stress on inclusive governance and democracy. These notions are much relevant to developing countries with plural societies where minorities constantly encounter discriminations and exclusions in governance structures. Theoretically argues that local government system is expected to function as people-centered government. It is expected that people must form the hub of it, and it should be an inclusive governance framework that integrates the interests of diverse groups of people. The decentralization of power and local government system under globalization is envisaged to formulate plans for local people with diverse needs, implement them with their participation and to have a mechanism that can empower them through a process of capacity building (Abeywardena, 1994; Cheema \& Rondinelli, 2007; Ahmad, 2005). Local governance is seen as a means of accommodating local citizens, weaker sections or local communities in governance, development planning, decision making and implementing the same, hence it is more informed of local needs and aspirations and can more efficiently respond to them (Zhou, 2009; Christine \& Nandani, 2003).

Nevertheless, the plantation community has been subjected to a long period of discrimination and 
marginalization in the public administration machinery and this community is used to being controlled by the plantation management, accepting it as the norm. As a result, even today they continue to live as a marginalized community, denied government employment and public services. They seem to passively accept this as their lot in life. Those who live outside the plantations seem to receive all the assistance and public services offered by the local government authorities without any discrimination. However, those living on the plantations are discriminated against with regard to state assistance. They do not receive the same benefits and public services as the others. Since this study focuses on the problems of the Tamils living on the plantations, they are referred to as plantation people. From colonial times, until recently the plantation people were segregated from the rest of the indigenous people and treated almost as semi-slaves. At the outset they were even prohibited from leaving the estates and they didn't have any contacts with the people outside. The opportunity of getting integrated with indigenous people was curtailed. They were denied and deprived of basic human rights and facilities enjoyed by the rest of the society thus resulting in their losing their self-esteem and dignity (Nadesan, 1993; Hittinayake, 2009). It's only against the social, economic and political background of the plantation people, that one can clearly understand the benefits and opportunities that they have derived from the decentralization of power to the regions and at the same time and discriminations they face in receiving benefits of public administrative services and services provided by the local government authorities. Then only one can understand its social impacts. Theoretically, decentralization and local government authorities provide wide range of opportunities for marginalized groups to access numerous services at the local level which remains as an effective mechanism to foster inclusive governance. Although Sri Lanka has long history of decentralization and local government system that did not much benefit the plantation community. This paper, therefore, explores central factors inhibit plantation people from enjoying local government services. This paper has five sections: first section provides rationale and background of the study, second section discusses methodology and theoretical aspects of the study, third section critically examines legal, political, institutional and other factors that hinder local government service delivery to the plantation community, fourth section propounds some suggestions emerged based on the findings and discussions to improve service delivery and fifth section provides conclusions, major arguments and contribution of the study.

\section{Objectives and Method of Inquiry}

This study intends to examine some major factors that hinder local government services to the plantation community, specially looking at the Pradheshiya Sabahss ${ }^{11}$ (Divisional Councils) service delivery. In this paper, we throw more light on legal and other obstacles that prevent access to local government services. The study employed qualitative approach and we gathered data from purposively selected five local government authorities from three different districts of Sri Lanka such as Kandy, Nuwara Eliya and Badulla. In addition, the plantation people living within the purview of these Pradeshiya Sabahs (PS), past and present political representatives of these local government authorities, public officials, trade union leaders, civil society leaders, estate managers and several others were interviewed to obtain primary data. We did conduct six focus group discussions in purposively selected PS such as Ambagamuwa, Nuwara Eliya, Lunugala and Pathahevaheta along with semi-structured and in-depth interviews. Further, a large number of published and unpublished documents were reviewed to obtain secondary data including PS Act, local government budget allocations, reports, local authorities laws, constitution of Sri Lanka and relevant works on local governance in general and Sri Lanka in particular.

\section{An Introduction to the Plantation Community in Sri Lanka}

In 1815 British brought the entire Sri Lanka under their control and introduced modern economic changes that led to the introduction of a new community of people with the cultivation of plantation crops in the hill country of then Ceylon. In the 1820s the British imported cheap labour from South Indian to employ them on these plantations. The workers who were thus brought in were all Tamils from South Indian states where rampant poverty had prevailed. At the beginning, they had come only as seasonal immigrant labour to work on the coffee plantations. Though they had started as temporary daily paid workers, later they brought their families and settled down permanently in the hill country districts in or about 1860s (Nadesan, 1993). The South Indian Tamils who settled down in Sri Lanka are generally referred to as Tamils of Indian Origin, Up Country Tamils, Plantation Tamils or Hill Country People. Even today $2 / 3$ of this community lives on the plantations and the rest in towns and villages near by the plantations.

The plantation people have maintained a distinct identity of their own different from that of the Sinhalese, Muslims or Sri Lankan Tamils. There are significant differences between indigenous Tamils of Sri Lanka and Plantation Tamils in terms of culture, traditions and language (Vijesandiran \& Ramesh, 2013; NPA, 2016).For almost 200 years they have lived and worked on plantations, and maintaining, protecting and promoting their 
own language, religion, history, culture and ancient traditions and customs. They have not severed themselves from their past, but continue to have a close relationship with their people in those Indian villages where they came from. At the same time, it is important to recognize them as a significant national ethnic minority group of Sri Lanka. However, in 1948 they were made 'stateless' and successive governments that came to power from the time of independence (1948) to late 1980s refused to accept them as citizens of this country and they were debarred from joining or holding high positions in the government service (Sahadevan, 1995;Kanapathipillai, 2009 \& Ibid). Further, they were deprived of socio-economic political rights for three decades which largely marginalized them from all forms of governance and right to access legally mandated public services in general and local government services in particular. Laws and policies that were formulated during this stateless period remain largely unchanged up to now, which still continues to be excluded them from local governance, though they have legally been granted citizenship rights in 2003 (Chandrabose and Sivapragasam, 2011; Vijesandiran \& Ramesh, 2013).

\section{Theoretical Discussion}

Though there are several theories and concepts on decentralization and local governance which did not touch more on status of minorities in local governance. The idea of decentralization denotes sharing of important responsibilities among the central, regional and local government institutions aiming at improving the quality of governance, efficiency and enhance the power and capacity of grassroots level government bodies (Perera, 1999). Hence, it becomes imperative that government institutions must be established at local levels, the needs of the people properly assessed and participation of people ensured through a process of decentralization of power. According to Aziz and Arnold (1996) decentralization of power takes the decision making authority to the grassroots levels and ensures access to government services. It provides broad opportunities for the grassroots people to participate in political and administrative activities and reinforces democracy at local level.

Unitary states achieve their goals of fulfilling development aspirations of local people and increasing their participation in development by establishing government institutions at grassroots level. It is envisaged that rural development can be accelerated through such strategies (Kothari, 1996; UNDP, 1999). For instance, the rural Panchayati Raj system prevailing in India has helped to ensure the social and economic enhancement of diverse people, human rights and social justice and has encouraged processes when all people are considered as equal in local government development activities, and encouraged their real participation. The political framework where power has been decentralized should offer equal opportunity to citizens to participate in the decision making process. If not, it is not at all possible to ensure an efficient local government system (Slater, 1994). If the process of decision making at low levels is restricted only to a particular social group or a handful of people, then decentralized local government system will lose its objective of ensuring welfare of all citizens. A genuine process of decentralization of power must ensure equal representation for all social groups and stakeholders without any discrimination whatsoever in the decision making process in development (Aziz \& Arnold, 1996). It is then only, all social groups will be able to achieve their own development and aspirations.

Cheema \& Rondinelli (2007), define decentralization as the transfer of authority, responsibility, and resources through de-concentration, delegation, or devolution from the center to lower level of administration. This explains that through decentralization, the power and authority be vested by central government bodies in the process of public policy-making are transferred to the local level administrative bodies. Thus, decentralization can be referred as a process of transfer or re-distribute powers and authorities to local level public and political institutions. Decentralization is seen as a flexible institutional mechanism to accommodate the varied priorities of diverse populations within a state and it enhances legitimacy of decision making. The greater level of minority participation and their voice in public sphere expected under decentralized system are also seen as stabilizing force for democracy and good governance (Yusoff et, al. 2015; Andrew, 1995; Akramov, 2008). Further, Cheema and Rondinelli (2007), argue that transforming power and authority from central government to sub-national administrative and local government units and opening the political process to widespread participation provide an institutional framework for local autonomy and empower local communities to pursue local aspirations. Lake \& Rothchild (2005) propound that decentralization would be an institutional mechanism that can potentially benefit both political minorities, who can be induced or compensated not to secede from the state, and political majorities, who gain countrywide acceptance of state institutions (cited in Yusoff et,al. 2015).

Another significant objective of decentralization of power to local government bodies is to include social groups who cannot normally participate directly in local level government activities, decision making and development planning. Local government bodies have to formulate the policy framework and mechanism and guarantee the enjoyment of human rights and other development opportunities of such groups. If not, decentralization of power and the establishment of a local government system will become mere institutional setups and meaningless 
rhetoric (Ghai, 2008; Robertson, 2002). It can be argued that in some circumstances, mere parliamentary democracy will not be an effective mechanism where ethnic majority tend to dominate governance. There should be some form of institutional arrangements to accommodate minorities -that is local governance. Thus, it is envisaged that the local government institutions should deliver the services by assuring the needs of the minority communities and formulate and implement essential policies to address them.

\section{Local Government Service Delivery and the Plantation Community}

Local government bodies had been existed in Sri Lanka from ancient times and decentralizing power to the local government bodies and providing public services by involving the people at the local level is nothing new in Sri Lanka. Decentralization had taken place in order to enable the people at grassroots levels to have easy access to the services and benefits offered by the government. They were also meant to be available to the people irrespective of their race, caste, religion or region they live in. These regional and local government bodies were expected to work closely with the local people and get them involved in governing their own regions.

In spite of this the plantation community has always remained marginalized and unable to obtain legally mandated public services or assistance from the local government authorities. Today this has become a major issue in national politics and policy agendas. The reasoning behind this marginalizing seems to be that the local government authorities do not accept the plantation community as part of the Sri Lankan society since they live on plantations and come under the control of the estate management, and they are considered to have no right to the public services available to the rest of the society. The estates are also seen as private domains and business ventures and as such those who work for these private company owners, it is argued, need not be given state assistance. The fact that in 1948, the plantation people were stripped of their civil and political rights seems to be the major cause that led to their marginalization from the government administrative machinery.

This discrimination that the plantation community is subjected to is considered a violation of the international Human Rights Laws which demands that all citizens of a country be treated as equals by the government and be provided with the same public services and facilities. Further, the Chapter three of the present (1978) Constitution of Sri Lanka states that the government should provide public services to all the citizens irrespective of their race, religion, language, place of birth or residence. Thus, it is clear that these local government bodies showing clear discrimination in providing their services to this community. There are about 2,200 plantations in Sri Lanka and about 250,000 families with one million people live on these plantations. The fact that the local government authorities show discrimination in providing their services to these people is not only a social, economic and political problem, but it also affects the social, economic and political development of the country as a whole (Vijesandiran \& Ramesh, 2013). It is notable that the social development and mobility that has taken place among other communities has not happened among the plantation community due to this discrimination that has deprived them of all facilities and opportunities to develop themselves. Although it has been perceived that local government system could be an effective mechanism to accommodate diverse and peripheral social groups in governance structures, it remains as rhetoric in the case of plantation community.

The non-extension of the local government services effectively to the plantations is the glaring defect found in the local government system of Sri Lanka. Various reforms and changes have been introduced in the local governance with a view to decentralizing power in Sri Lanka. However, no reform arrangements have been put in place to absorb the plantation people into the local government system. When considering all this, it is doubtful whether there is meaningful decentralization of power and a local government system in Sri Lanka that can benefit all social groups and provide opportunities for all to participate in governance. In short, it can be stated that the implementation of a local government system that has been accepted in principle is being observed in the breach. The problems and challenges that the plantations people face in the matter of access to services of the local government authorities are not nationally known or they are deliberately swept under the carpet due to political reasons. As a consequence, they have to rely entirely on the plantation sector or management for everything and cope with the oppression and control practised by the estate managements (Vijesandiran, 2011). The study found the following impediments that preclude the plantation people's capability to access services offered by the local government authorities.

\section{Discriminatory Provisions in the Local Government Authority Act}

The Pradeshya Sabha Act of 1987 which is in force now is an extension of an amended Village Committees Ordinance of 1937, The District Development Councils Act of 1980 and the Village Councils Law No 06 of 1964. The interpretation of the above Village Committees Ordinance and the Village Councils Law and their inherent regulations have been absorbed into the District Development Act and later on absorbed into the current Pradeshya Sabha Act (Divisional Council Act). These Acts had apparently excluded plantations from local 
government service delivery. Interestingly, legal provisions of the above Acts applying to the current Pradeshya Sabhas Act of 1987 as well, which has led to continuation of discriminatory provisions even in the current local government Act. For instance, section 225(2) of the Act stipulates that the Pradheshiya Sabhas will constitute the by -laws of the above Acts - which means plantations do not fall under the administrative purview of the local government authorities in general and Pradheshiya Shabhas in particular. To put it differently, the above laws which exclude plantations from local governance were enacted during the stateless period of the plantation community and interestingly, several provisions of those laws reflect in the current Pradeshiya Sabha Act, therefore, plantations and its settlements have not been incorporated in its administrative purview.

In 1964 when the Village Council Law was passed, most of the plantation people had lost their citizenship rights and they were stateless. Today the situation is different. Nevertheless, the adoption of legal interpretations found in the previous local government law has paved the way for continuous discriminations and neglect against the plantations people under the present local government system. As long as these legal provisions are not amended, it is inevitable that the attitude of legal neglect practised by the local governments on the plantation people will continue. These activities are a violation of the fundamental rights enshrined in Chapter III of 1978 Constitution that acknowledges the equal rights of every citizen of the country. This reveals another important fact is that although the plantation people were granted legal citizenship, the successive governments of Sri Lanka did not make considerable efforts to reform existing Laws or Acts and policies to enable them to enjoy the benefits of legal citizenship as same as other citizens of the country -which fundamentally affected their socio-economic and political development. Sen (2001) argues that citizenship is integrally connected with the possible enhancement of human capabilities; hence granting of legal citizenship removes some of the 'unfreedoms' that place people at risk (cited in Blitz \& Lynch, 2011: 10). However, in the case of plantation people granting of citizenship have not substantially helped enhance human capabilities owing to existing laws and policies.

Section 2(1) of the Act further states that plantations have not been included in the definition of village or urban area as well as under the Pradeshya Sabhas Act the estates are demarcated as private property. Historically, right along, the people of the plantation had not been regarded as Sri Lankan citizens and they were perceived and categorized as a society of migrant workers, stateless or Indian workers and their life confined to tea, coffee and rubber estates. As a result, the plantation areas were not absorbed into the public administration machinery of Sri Lanka and they formed a peculiar social structure within the Sri Lankan society. Furthermore, when they formulated the laws for the local government bodies, several legal provisions are included regarding service delivery to the plantation people utilizing state public finances being prohibited. Therefore, the estates and the areas of their settlements were not brought into the administrative structure of the local government. Owing to these legal provisions estates are incapable of being absorbed into their territories of local government. Therefore, in compliance with Section 2(1) of the Pradeshya Sabha Act, the estates and the people's settlement are regarded as having been excluded from the governance and administrative structures and there has been legitimate implication in delivering public services to the plantation community.

Further, Section 19 (xiv) and 19 (xxii) of the Pradheshiya Sabha (PS) Act states that it can allocate the public finances of the PS only for rural development purposes - plantations do not fall under the classification of 'rural'. As the estates do not come under the definition of villages, the PS Act has no provisions to extend the public services to the plantation sector. Similarly, the section 33 of the PS act prohibits service delivery to the plantations areas as it is managed by the private plantation companies and the local government authorities presuppose that social welfare of this community should be looked after by the plantation companies to which they attached. This argument explicitly violates citizenship rights along with various fundamental human rights. This leads to the view that the plantation people have been purposely and legally excluded from access to public services. The section 33 of the PS Act delineates plantations as private business entity and justifies that PS does not have powers to penetrate in plantations owned by private companies. This section has been one of the major obstacles to deliver services.Accordingly, since the estate settlements have not been absorbed into the control or the administrative structure of the Pradeshya Sabhas, it is pointed out that any effort on the part of the Pradeshya Sabhas to utilize their funds for the physical development of the plantation people is violating and contradicting the rules and regulations of the present Pradeshya Sabhas Act.

\subsection{Non- acceptances of Estate Settlements as Part of Village}

According to the Pradeshya Sabha Act of 1987 the villages have been defined as part of the territory of the Pradeshya Sabhas. The total land areas of Sri Lanka have been categorized as urban areas, villages and estates (plantations). Accordingly, the households in the urban areas have been absorbed into the territories of the Municipalities, and the Urban Councils, and the villages are absorbed into the territories of the Pradeshya Sabhas. Each and every estate ${ }^{2}$ division has the aspects and characteristics that are found in the villages. Therefore, all 
the estates must have been acknowledged as villages and included into the category of villages within the territories of the Pradeshya Sabhas. However, it was never attempted to include them and it is not clearly delineated as to which local government bodies the estates belong to. On the other hand, government statistics reveal that there are 35, 440 villages in Sri Lanka (Department of Census and Statistics, 2011), and interestingly, the estates are not included as integrated parts of these clusters of villages. The settlements in estates have been identified in the Sri Lankan map as economic centres and plantation crop lands and buildings and not as human settlements. As a result, the estates have never found a place within the public administration structure and consequently the plantation people are deprived of the rights for public services which are freely enjoyed by other citizens. Therefore, they are unable to function as full citizens in local governance with equal rights and entitlements with the rural population.

\subsection{Denial of Language Rights}

The Article 10 of the Universal Declaration of Human Rights, Chapter IV of the Sri Lankan Constitution, the $13^{\text {th }}$ Amendment and $16^{\text {th }}$ Amendment to the Constitution, all emphatically recognise language rights of all citizens. The Sri Lankan Constitution and its amendments confer the right for its citizens to correspond and communicate with government institutions in their mother tongue and receive information from these institutions. Specifically, article 2 (b) of the $13^{\text {th }}$ Amendment of 1987 stipulate that Tamil shall be an official language and the $16^{\text {th }}$ Amendment of 1988 stipulates that Sinhala and Tamil shall be languages of administration of government institutions. However, they are merely confined to books of statutes and the local government institutions have not taken ample measures to implement them. Therefore, working of local government authorities mostly take place in Sinhalese language -spoken by ethnic majority and there has been lack of willingness among public officials in undertaking administrative transactions in Tamil language at the local level which has substantially limited access to local government institution and eventually led to low trust in these institutions.

Even today there is grandiloquent rhetoric about bilingual and trilingual policies and programmes and present government more inclined to address linguistic grievances of minorities. However, there is a continuing linguistic issue faced by the plantation people in public service delivery of local government bodies functioning in the plantation areas. The local government bodies in areas densely populated by the Tamil speaking people do not appoint sufficient number of Tamil speaking government officials. Access to an efficient and accountable public service continues to remain a dream as there are no Tamils from the plantation sector in high ranking administrative posts of the local government institutions which serves as a stumbling block in this matter. The table 1 shows the number of Tamil public servants in selected Pradheshiya Sabhas which are highly concentrated by plantation population.

Table 1. Tamil public servants in selected local government authorities

\begin{tabular}{llccccc}
\hline District & Pradheshiya Sabha $^{2}$ & \% of Tamils & Total public servants & Sinhalese & Tamils & Muslims \\
\hline \multirow{2}{*}{ Nuwara Eliya } & Ambagamuwa & 77 & 24 & 13 & 09 & 02 \\
& Nuwara Eliya & 78 & 30 & 18 & 12 & - \\
\hline \multirow{2}{*}{ Badulla } & Lunugala & 69 & 20 & 19 & - & 01 \\
& Passara & 54 & 26 & 25 & 01 & - \\
& Haputale & 69 & 27 & 26 & 01 & - \\
& Haldumulla & 66 & 12 & 10 & 02 & - \\
\hline Kandy & Panvila & 63 & 20 & 16 & 02 & 01 \\
\hline
\end{tabular}

Source: Field Study, 2013

This table shows only the staff category officials and did not cover supporting staff -lower category. This table depicts the number of Tamil public officials in randomly selected Pradheshiya Sabhas (PS) in three districts. When we compare with the $\%$ of Tamil population in each PS, one can argue that there is apparent discrepancy between percentage of Tamil population and available Tamil officials. As shown by this table, large number of Sinhalese officials in Tamil majority areas remains as one of the major obstacles to gain access to public services in the plantation areas. 


\subsection{Vast Population}

The Pradeshya Sabhas functioning close to the estate areas have a vast population, particularly the Ambagamuwa, Nuwara Eliya, Kotmale and Walapane Pradeshya Sabhas are prominent Pradeshya Sabhas in Sri Lanka that control the largest populations (Vijesandiran, 2011). Out of these Pradeshya Sabhas, the Ambagamuwa and Nuwara Eliya Pradeshya Sabhas have comprised of 150,000 populations and the others have a population of about more than 100,000. National policy for creating PS stipulates that for every 40,000 populations one PS can be established, but the practice is quite different in the plantations areas where local authorities are highly populated which has substantially limited the access to services and resources and eventually led to high competition in sharing resources and services with ethnic majority in these areas. In order to ensure local government services and people participation, several Pradeshya Sabhas have been established even in areas where the population is lower than 10,000. For instance, the total population in the district of Hambantota (located in Sinhala majority area) is 383,361 and it has 10 Pradeshya Sabhas. In the case of Nuwara Eliya (Tamil majority) district, the total population is 736,236 , but there are only 5 Pradeshya Sabhas are in operation.

Table 2. Pradeshya sabhas with low population and the ethnic configuration

\begin{tabular}{|c|c|c|c|c|c|}
\hline \multirow[b]{2}{*}{ Pradeshya Sabhas } & \multirow[b]{2}{*}{$\begin{array}{r}\text { Total } \\
\text { Population }\end{array}$} & \multicolumn{4}{|c|}{ Population based on ethnicity } \\
\hline & & $\begin{array}{r}\text { Sri Lankan } \\
\text { Tamils }\end{array}$ & $\begin{array}{r}\text { Sri Lankan } \\
\text { Tamils }\end{array}$ & $\begin{array}{r}\text { Plantation } \\
\text { Tamils }\end{array}$ & Muslims \\
\hline Padavisiripura & 11,858 & 11,846 & 10 & - & 01 \\
\hline Padiyathalawa & 18,209 & 18,091 & 28 & 02 & 87 \\
\hline Maha-Oya & 20,715 & 20,655 & 15 & 02 & 742 \\
\hline Gomarankadawala & 7,339 & 7,313 & 25 & - & 01 \\
\hline Morawewa & 7,946 & 5,750 & 888 & 03 & 1300 \\
\hline Lahugala & 8,900 & 8,254 & 645 & - & 01 \\
\hline
\end{tabular}

Source: Department of Census and Statistics, Sri Lanka, 2012.

The government follows the highly questionable practice of making financial allocation to the Pradeshya Sabhas without paying attention to the size of the population or the scale of development needs. Rightfully, when one considers facts on the basis of population, Nuwaraeliya ${ }^{4}$ should have at least 15 Pradeshya Sabhas whereas it has to be satisfied with only 5 Pradeshya Sabhas especially those of the plantation areas with those of some other areas of the country. As a consequence, the district is compelled to receive a very low level of financial allocation much below the level of the allocation it is entitled to. Under such circumstances, unless a sufficient number of Pradeshya Sabhas are established according to the population, the plantation people will not be fully able to enjoy the services of the Pradeshya Sabhas. Though the relevant proposals and suggestions have been accepted by the government in this regard the shift or actions in that direction are kept in abeyance. It is relevant to have a comparative study of the situation prevailing in regard to population and the Pradeshya Sabha practice. The following table shows that Pradeshya Sabhas have been established for a low number of people in ethnic majority areas such as Padiyathalawa, Maha Oya and Lahugala. In contrast, in Nuwara Eliya district 2 Pradeshya Sabhas function for a population of more than 150,000 people and the resources and financial allocations provided to the Pradeshya Sabha comprised of 8,900 persons is given to the Ambagamuwa and Nuwara Eliya Pradeshya Sabhas which have a population of 150,000 people. Similarly, the total population of the Trincomalee district is 378,182 and there are 11 Pradeshya Sabhas functioning in this district (Department of Statistics, Sri Lanka, 2012). Even in this district several Sinhala only Pradeshya Sabhas have been established to serve the interests of the Sinhalese. The table 2 gives more details on population density and available PS in selected districts of Sri Lanka.

This study reveals that although plantation people were granted citizenship rights, they are still unable to reap the benefits of citizenship owing to legal and institutional discriminations. Citizenship doesn't signify a mere existence as a member under a nation state. It means that state has the duty to provide the basic environment for a citizen to live as an active participant enjoying rights and privileges. It has long been argued that citizenship rights enable individual belonging to disadvantaged groups to effectively access numerous services that are legally mandated -this argument does not coincide with the case of plantation Tamils in Sri Lanka.This shows 
that successive governments of this country have not been practiced the policy of inclusive democracy to address grievances of minorities -especially, ethno-centric politics or ethno nationalism, discriminatory laws, policies, practices and power politics have effectively marginalized plantation people from local governance which considerably subverted the quality of government, inclusive democracy and fundamental principle of impartiality and fairness of public and political institutions.

\subsection{Financial Constraints}

Generally, the financial deficits are the bane of the local government institutions in Sri Lanka and it led to lack of effectiveness and efficiency.The continuous state of financial deficits has adversely affected the genuine expectations of the local government bodies. When local government institutions with low population such as 10,000 and 20,000 face massive financial crises, the situation of the local government institution that function in areas with massive populations of plantation people can be imagined easily. In other words, there has been a serious financial crisis in local government authorities that function in the plantation areas; this is mainly because of larger population and geographical extent that these institutions cover up. Apart from legal barriers to service delivery of local government authorities, scarcity of financial resources is also a significant reason. The meagre financial resources obtained through taxes are spent for the needs and expectations of the tax-payers. Though there are no legal provisions to the effect that service delivery should only be to the tax payers, it is followed as a matter of practice. On account of this reason, even the meagre finances that are allocated diverted towards the welfare of the villages. As there isn't sufficient political representation for the plantations people in the local government institutions excepting Nuwara Eliya district, a huge portion of the finances find its way into the villages. As a result, development work in the plantation areas is neglected.

Furthermore, as there is a notion amongst the majority politicians and administrators that any development work for the estate people is the responsibility of the estate administration, the use of finances of local government bodies to the plantations is restricted. Since there is significant political representation in the Provincial Council and the local government institutions of the Nuwara Eliya district, even among situations of intense conflict at least a few services trickle down to the people of the plantations. Furthermore, by the allocations from the budgets of the central government ministers, members of the parliament and the provincial council members and NGOs some development projects are launched by the local government bodies in estate areas.

\subsection{Large Geographical Area}

It is an aspect of remarkable importance that the territorial area of the Pradeshya Sabhas that function in the plantation areas is huge. Particularly the territorial areas of the Nuwara Eliya and Ambagamuwa are 475 and 465.4 Square Kilometers respectively. As the Pradeshya Sabhas that include plantation areas control a huge extent of land, the plantation people find it difficult to approach them Sabhas in order to address their needs. Furthermore, the offices of these Pradeshya Sabhas are village centred and they are far away from the estate settlements.

\subsection{Interference of Trade Union Politics}

The Prdeshya Sabha members and the related political bodies are trade-unionized; therefore, the members utilize the resources and powers to achieve the targets of the trade unions which they patronize. As a consequence, they don't have the intention of taking steps to fulfil the development needs of people of the plantations or to address political instability in the local government bodies and expand its powers. Further, as these members belong to different trade unions, therefore, they do not have much interest to take collective action, put forward their common demands and bring about relevant changes in the Pradeshya Sabha law in order to absorb the total estate areas by way of achieving complete public service delivery to these people.

\subsection{Governance under the Indian Labour Ordinance}

The Indian Labour Ordinance passed in 1930 which refers plantation workers' wages, housing, education, health and drinking water and it confers the right of taking decisions in matters of workers' welfare and development to the estate management. Under this law, no outsider can enter the estates or act in any matter. They should get previous approval from the estate manager. Even today the estate workers are administered under the Indian Labour Ordinance. This Ordinance is viewed as the relevant law that governs the workers in privately owned estates. Consequently, the plantation people are kept outside the parameters of the general law of the country. Prior approval from the estate management is very essential in any matter such as housing, self-employment and cultivation that the workers engage in.

From this point of view, the Indian Labour Ordinance is also one of the contributory factors for the non-extension of the services of the local government bodies to the estates. Not only the local government bodies, 
but even other government institutions put forward the argument that they need not extend their services to the people of the plantations which are functioning under private administrations and the attitude of gross neglect and unconcern persists. Furthermore, before services are extended to the estates, government officials have to wait for the approval of the estate management and they do not like this state of affairs. Though recently there are a few changes in this respect, there are still certain impediments. If the estate households are brought under the administrative set up of the local government bodies, they can enjoy the benefits of all the services. They can pay taxes and thereby will gain entitlement for access to the services -this is the pressing need of the present. However, this is not an easy task -the estate management or the plantation company owners should express consent to these changes.

\subsection{Restricted Participation of People}

In the preamble of the Pradeshya Sabhas Act it is mentioned that this Act is established with a view to giving the people the great opportunity of constructive participation in matters of local administration and development activities. There are several consultative committees in the Pradeshya Sabhas established with a view to giving advices on matters of housing, social development, technical services, finance, policies, planning, environmental preservation and public utilities. It is mentioned that in these committees in addition to the representatives, citizens can be included to ensure people participation in local governance and democracy. However, as far as the people of the plantations are concerned, they appear to be in a situation where they cannot participate legally and constructively in any of the above activities which challenge the fundamental expectation of local government such as inclusive democracy, inclusive state, deliberative democracy, democratic citizenship and eventually quality of public and political institutions. The chief reason for these people's backwardness in housing, social development, technical knowledge, environmental development and downgraded welfare measures is attributed to the denial of the right of legitimate participation in local government institutions. The findings of previous studies have revealed that the lack of a proper mechanism to ensure people's participation is the root cause of all evils that have led to the non-fulfilment of the expectations of the local government bodies (Kothari, 1996; Hettige, 2003; Christine, 2003; Gunawardena, 2010).

\section{Recommendations to Inclusive Local Government Service Delivery}

Based on the findings, the study propounds some recommendations to effectively accommodate plantation community in the service delivery mechanism of local government authorities. These recommendations may be useful in other contexts where local government services limited to certain sections.

\subsection{Declaration of Estates as Villages}

If a solution is needed for the challenges faced by the people of the plantation in gaining access to the services of the local government bodies the estates must be declared as villages and through this step the entire plantation areas must be included into the administrative boundaries of the Pradeshya Sabhas and other administrative institutions.

\subsection{Bringing Amendments to the Pradeshya Sabha Act}

The services of the Pradehsya Sabhas can be extended to the people of the plantations by effecting the necessary amendments to the Pradeshya Sabha Act. Particularly those provisions in the Pradeshya Sabha Act that are inimical to service delivery to the plantations have to be first abolished from the Act. This can also be achieved by an affected person in service delivery of the Pradeshya Sabha filing a fundamental rights application in the Supreme Court. On the other hand, a civil society organisation working to ensure human rights can get the signatures of all the affected people and file a fundamental rights case in the Supreme Court. It is possible to file a case under Article 12(11) of the chapter III of the Constitution of Sri Lanka which states that no citizen should be discriminated against on grounds of race, religion, language, nationality, gender, political affiliation or place of birth. There is another way to approach this problem is that the Pradeshya Sabha Act is a statute of the Parliament, so, it can be amended by the Parliament. Parliament is vested with the necessary power to amend and formulate laws - specially Sections 1(2), 33, 19 (xiv), 19 (xxi) 134(4) and 225 (2) of the Pradeshya Sabha Act have to be amended or rescinded to deliver local government services to the plantations.

\subsection{Establishing a National Council of Local Government}

A national council of local government must be established to ensure minority rights in local politics and mechanisms to ensure full participation of the plantation people - positive discrimination policies must be put in place to ensure equal service delivery to all. In order to achieve this, political parties of the plantations and civil organisations must apply unceasing pressure on the Sri Lankan government. 


\subsection{Establishing new Local Government Authorities}

The number of local government bodies now functioning in the plantation areas is hardly sufficient. The main reason for this state of affairs is the non -inclusion of the plantation people into the local government system. Under these conditions the government should establish new local government bodies in these areas and ensure equal service delivery to all. Racial or communal political thinking in this regard would lead as nowhere. The Sri Lankan government has to carry out this task accepting the inescapable fact that the plantation people form one of the national ethnic groups and showing the good will and gratitude towards community who have contributed immensely to the national economy for more than 200 years and as a group who have been denied and deprived of their civil, political, social and economic rights for a very long time and in recognising the fact that their labour is immensely valuable in increasing GDP of the country.

\subsection{Establishing an Affirmative Action Mechanism}

The government has to put in place an anti-discriminatory mechanism to do away with activities of prejudice caused to the plantation people by local government bodies and ensure service delivery on the basis of equality. The rule of law and democratic values can be strengthened and promoted through this measure. Affirmative action or policy of positive discrimination accepted by the whole world which is adopted with a view to enhancing the situation of balanced development to backward groups of people in society must be put in place. Under this mechanism, special allocation of seats in the local government bodies and resource allocation can be also considered.

\subsection{Creating Political Pressures}

Above all, we have to strive to address this issue by way of exerting political pressures. Whatever the nature of the social, economic or political issue, it can be addressed only through policies, resolutions and statutes accepted and passed in the legislature. Though adequate international pressures are generated, the final solution will depend on concrete actions in the national parliament. Those pressures can only create an environment favourable for changes. The plantation political leadership has to garner the support of the political parties of ethnic majority and exert pressure on the government. This pressure should become a continuous feature in the parliament and the cabinet. This should lead to a favourable environment of persuading them to bring about amendments to the Pradeshya Sabaha Act of 1987.

\subsection{Increasing People Participation}

Activities must be initiated by way of raising awareness among people regarding the implications of this issue and protest against this injustice. This will lead to a situation favourable to the amendment of laws and changes in policies. This has to be transformed into a national issue by the public and civil organisations by sending petitions continuously to the Presidential Secretariat, Ombudsman, the Consumer Affairs Authority and the Tribunal for Administrative Appeals. The plantation trade unions, political organisations, NGOs, business organisations, welfare groups, religious and voluntary organisations, mass media and intellectuals should become part of this process of agitation behind the slogan and theme of justice to the plantation people.

\section{Concluding Remarks}

The preamble of the Pradeshiya Sabha Act states that this Act is being enacted with a view to providing the broadest possible opportunity to the people for efficient participation in the process of decision making in matters related to local administration. However, this study has eloquently brought out that such an opportunity has not been fully given to the Plantations people though they hold equal rights and entitlements. On the other hand, it has revealed that though there are provisions in the law that govern the functioning of local government authorities to establish local committees and pave the way for genuine people's participation, the people of the plantations have never been afforded these opportunities. The study has identified several factors that contribute towards the violation of the rights of plantation population - such as legal impediments, shortcomings in the structure of the local government institutions, political and administrative marginalization, the plantations being viewed as possessions of business enterprises, the restriction in the utilization of finances of the local government bodies, denial of enjoyment of equality and human rights and lack of sufficient political representation have all been pinpointed as contributory factors to thisstate of affairs. This study has identified the failure of the local government authorities which are the closest government institutions to the people to include the plantation areas into their administrative territories as a systematic exclusion in all forms of governance and democracy.

Right from the time of independence, there have been instances where attention has been focussed on and priority given to the interests of rural population - public administration and service delivery have been taken to 
their feet through decentralisation. Nevertheless, people of the plantations have been entirely left out of these processes and it is an objective reality that policy makers and Sri Lankan state have so far not acknowledged rights of the people of plantations to gain access to public services. This study has eloquently brought out that reform in the contemporary Pradeshya Sabha Act, full political representation and broad autonomy in utilisation of finances are essential to ensure that the plantations people are absorbed fully into an inclusive service delivery mechanism. At the same time, financial autonomy, sufficient allocations, use of the Tamil language and appointment of Tamil speaking officers have to be guaranteed.

It is also relevant to note that where political divisions are defined by ethnicity, ethno-nationalism, religious, linguistic, tribal and party affiliations, there may be many layers of discriminations that undermine the potency of citizenship rights by reinforcing discriminatory laws, policies and structures. Some scholars argue that bond of nationality with a state can evidently have a positive impact upon the individual's enjoyment of rights and quality of life; it can put an end to years, even a lifetime of exclusions and discriminations. However, this is not always the case -although plantation people were granted citizenship, they are unable to enjoy the full benefits of it. Theoretically argued that decentralization and local government helps empower weaker sections of the society by accommodating them in the governance structures - in the case of plantation Tamils, decentralization and local government systems have systematically precluded them from enjoying legally mandated services of local authorities. It is evident that although plantation people were granted legal status of citizenship, the Sri Lanka government has not reformed relevant laws and policies or created institutional mechanism to enable them enjoy public services and other rights in a substantial manner. This shows that state responsibility with regard to stateless people would not end up only with the granting legal status, importantly, it has to create conducive environment to reap the benefits of citizenship rights denied for decades.

\section{References}

Abhaywardena, H.A.P. (1994). Decentralization and responsive government: A Sri Lankan experience.In Nanayakara, G. (Eds.), Public accountability and the role of the citizen in government. Postgraduate Institute of Management. Colombo: Sri Jayawardanapura University of Sri Lanka.

Ahmad, J. et al. (2005). Decentralization and service delivery. World Bank Policy Research Working Paper 3603. World Bank: Washington. https://doi.org/10.1596/1813-9450-3603

Akramov, T. K. (2008). Decentralization and public service delivery to the rural poor. International Food Policy Research Institute:Washington.

Andrew N. P. (1995). Decentralization a way forward for rural development? Agriculture and Natural Resources Department. World Bank: Washington.

Aziz, A., \& Arnold, D. (1996). Introduction. In A. Aziz \& D. Arnold (Eds.), Decentralized governance in Asian courtiers. New Delhi: Sage. https://doi.org/10.1007/978-1-4757-2469-1_1

Blitz, B.K.,\& Lynch, M. (2011). Statelessness and the deprivation of nationality. In B.K.Blitz, \& M. Lynch (Eds.), Statelessness and citizenship: A comparative study on the benefits of the citizenship. London: Edward Elgar. https://doi.org/10.4337/9781849808996.00006

Chandrabose, A. S., \& Sivapragasam, P.P. (2011). Red colour of tea: central issues that impact the tea plantation community in Sri Lanka. Kandy: Human Development Organization.

Cheema, G. S., \& Rondinelli, D. A. (2007). From government decentralization to decentralized governance. In G. S. Cheema \& D. A. Rondinelli (Eds.), Decentralizing governance: emerging concepts and practices. (pp.1-20). Washington D.C: Brooking Institute Press.

Christine, B. (2003). Governance and local government reforms: recent reform debate in Sri Lanka. In S.T. Hettige, et al. (Eds.), Local government and conflict management in Sri Lanka. Colombo: Development Studies Institute of the University of Colombo.

Christine, B., \& Nandani, G. (2003). Empirical study on local governance in three regions of Sri Lanka: framework analysis and methodology. In S.T. Hettige et al. (Eds.), Local government and conflict management in Sri Lanka. Colombo: Development Studies Institute of the University of Colombo.

Department of Census and Statistics. (2012). Statistical pocket book: Colombo.

Ebel, R. (1998). Logic of decentralization and worldwide overview. New York: UNDP.

Ghai, Y. (2003). Public participation and minorities. London: Minority Rights Group International.

Gunawardena, A. (2010). Local government under devolution. In Y. R. Amarasinghe et al. (Eds), Twenty two 
years of devolution: An evaluation of the working of provincial council in Sri Lanka. Colombo: Institute for Constitutional Study.

Hettige, S.T. (2003). Local government in the Central Province: Ambagamuwa Pradeshiya Sabha. In S.T. Hettige et al. (Eds.), Local government and conflict management in Sri Lanka. Colombo: Development Studies Institute of the University of Colombo.

Hitinayake, G. (2009). Root causes for poor delivery of government services to the estate community and present status of their social security.LST Review, 19(258), 1-17.

Kanapathipillai, V. (2009). Citizenship and stateless in Sri Lanka: the case of the Tamil estate workers. London: Anthem Press.

Karunanayake., M.M.,\& Abhayaratne, M.D.C. (2002). Redefining regional development in Sri Lanka: realities and challenges. CMU. Journal, 1(3), 303-319.

Kothari, R. (1996). Issues in decentralized governance. In Abdul Aziz, \& David D. Arnold (Eds.),Decentralized governance in Asian courtiers. New Delhi: Sage.

Nadesan, S. (1993). A History of the Up-Country Tamil people. Hatton: Nandalala.

Perera, B. (1999). Impact of decentralization on rural development at the local level in Sri Lanka. In Decentralized rural development and the role of self -help organizations. United Nations: Food and Agricultural Organization.

Pradheshiya Sabha Act No.15 of 1987. Colombo: Government Printers.

Robertson, W. (2002). Overview of decentralization worldwide: stepping stone to improved governance and human development. New York: UNDP.

Sahadevan, P. (1995). India and overseas Indians: the case of Sri Lanka. Delhi: Kalinga Publications.

Slater, R. (1994). Accountability and local government in the UK and Sri Lanka: A comparative perspective. In Nanayakara, G. (Eds.), public accountability and the role of the citizen in government. Colombo: Postgraduate Institute of Management.

The Constitution of the Democratic Socialist Republic of Sri Lanka. (1978). Colombo: Government Printer.

UNDP. (1999). Evaluation of UNDP role in decentralization and local governance. Working Paper. UNDP: New York.

Vijesandiran, S. (2011). Exclusion of estate residential communities from the Pradeshiya Sabhas' Service delivery system (unpublished report). Kandy: Institute of Social Development.

Vijesandiran, S.,\& Ramesh, R. (2013). Local government service delivery and the plantation community: A human rights perspective. Hatton: Estate Community Solidarity.

Yusoff, M.A. et al. (2015). Decentralized administration and minority accommodation in Sri Lanka: analyzing status, issues, challenges and prospects. Mediterranean Journal of Social Sciences, 6(4), 533-542. https://doi.org/10.5901/mjss.2015.v6n4s1p533

Yusoff, M.A., Sarjoon, A., \& Hassan, M.A. (2016). Decentralization as a tool for ethnic diversity accommodation. A conceptual analysis. Journal of Politics and Law, 9(1), 55-64. https://doi.org/10.5539/jpl.v9n1p55

Zhou, Y. (2009). Introduction. In Y. Zhou (Eds.), Decentralization, democracy and development. Washington: The World Bank. https://doi.org/10.1596/978-0-8213-7999-8

\section{Notes}

Note 1. Responsible for providing a range of services to grassroots people including road constructions, public health, sanitation, housing, libraries, public parks, drains, environment protection, early childhood educations and etc. These institutions largely function at the village areas and mandated to look after development and social needs of village communities.

Note 2. The term 'Estate' and 'Plantations' are interchangeably used in this article, both refers to same meaning.

Note 3. Local government authorities are divided into three categories in Sri Lanka: they are Municipal Councils, Urban Councils and Pradheshiya Sabha (Divisional Councils) in which PS mostly serves at the village level. 
Note 4. Plantation people accounts to $58 \%$ of total population of the district.

\section{Copyrights}

Copyright for this article is retained by the author(s), with first publication rights granted to the journal.

This is an open-access article distributed under the terms and conditions of the Creative Commons Attribution license (http://creativecommons.org/licenses/by/4.0/). 